\title{
THE AIRLINES' RECENT EXPERIENCE UNDER THE RAILWAY LABOR ACT
}

\author{
ARTHUR M. WiseharT*
}

\section{INTRODUCTION}

No reader of newspapers need be told that the recent past has been eventful from a labor relations point of view in the air transport industry, and many travelers by air can recount vivid personal experiences illustrative of travel problems and inconvenience caused by strikes on the airlines. ${ }^{1}$ This article describes factors underlying these disturbances, outlines the applicable labor laws, and summarizes recent developments. First in order, however, is a brief description of those aspects of the air transport industry having a particular bearing on its labor relations:

A. Strikes are especially crippling to the airlines. Air carriers deal in services, not goods. Consequently, they cannot build up inventories to provide revenue or forestall loss of trade when a strike occurs. Moreover, as transportation is provided continuously, an interruption of service affects the public immediately. ${ }^{2}$

B. Since the transportation provided is national and international, as well as local, airline operations take place in a variety of labor markets.

C. The industry is relatively new and dynamic, having a rapidly changing technology. Although its routes, fares, and operations are subject to governmental regulation, it is highly competitive. Competition has been sharpened by the Civil Aeronautics Board's policy of establishing parallel routes. One aspect of competition is the race to acquire and put new equipment into operation. The new equipment entails high capital expenditures and brings about a rapid rate of obsolescence.

D. The jobs performed by the organized employees run the gamut of specialization, from highly-trained pilots to relatively untrained employees performing cleaning services.

E. The employees are organized on a "class or craft" basis, so that each carrier must deal with a number of unions.

* B.A. I950, Miami University (Ohio); M.P.A. 1953, Wayne University; J.D. I954, University of Michigan. Member of the New York bar; General Attorney, American Airlines, Inc.

1 Airline strikes forced the cancellation or disruption of travel plans of over 2,500,000 passengers in 1958. Moreover, airline employees lost more time due to strikes in $195^{8}$ than in the previous 20 years combined. Air Transport Association of America, Air Transport Facts and Figures 4 (20th ed. 1959). The injury from strikes does not, of course, include the harassment from numerous strike threats. See the tabulations of strikes and strike threats in Six Carrier Mutual Aid Pact Approval Proceedings, No. 9977, Joint Brief of the Airline Parties, CAB, I959, tables 3 and 4 .

2 The situation is similar in other service industries. See Ievinson, Railway Labor Act-The Record of a Decade, 3 LaB. L.J. 13 (1952); Tower, Labor Relations in the Broadcasting Industry, 23 Law b Contemp. Prob. 62, 63 (1958). 


\section{Factors Underlying Recent Labor Disturbances}

The introduction of jet aircraft has been a key factor in recent airline labor relations problems. Because of increased capacity, the new equipment has given rise to alleged fears of technological unemployment, a specter periodically raised by airline unions since the beginning of air transport services. ${ }^{3}$ These allegations supplied arguments used to support the demands of the mechanics for severance pay and a large wage increase, and the demands of the pilots that they be given the jobs of the flight engineers or, in the alternative, that an additional pilot be put in the cockpit of jets. ${ }^{4}$ The flight engineers, of course, put up a strong defensive struggle to retain their position. ${ }^{5}$

In the past, because of technological improvements and continued growth, the air transport industry expanded very rapidly ${ }^{6}$ and was able to absorb increasing costs. $^{7}$ Recently, however, costs have begun to outstrip growth, ${ }^{8}$ and just when capital requirements for new equipment became highest, profits dipped. ${ }^{9}$

In 1956, a general passenger fare investigation was inaugurated by the $\mathrm{CAB} .^{10}$ Although it has dragged on for four years without a final decision, an interim fare

${ }^{3}$ Past experience in the industry has not supported claims of technological unemployment. See note 6 infra.

'See E. B. McNatt, Labor Relations in the Air Transport Industry, I947-I957, at 20-21 (I958). Recent settlements provide for three pilots and a flight engineer in the cockpit of turbojet aircraft. Piston aircraft were operated with two pilots and a flight engineer. A description of the historical and functional relationship between flight engineers and pilots is contained in the reports of Presidential Exergency Bonfo No. 120, Report (I958); Presidential Emergenct Bonrd No. I2I, Report (I958).

EFor a report of continuing friction, see N.Y. Times, March 16, 1959, p. 53, col. x. The Wall Street Journal for March II, 1959, p. I, contains a report of various personnel problems and complaints resulting from the introduction of jet aircraft.

- The growth of the air transport industry is depicted in the following chart from Arr TransporT Association of America, op. cit. supra note $x$, at 8:

THE AIRLINE STORY

Ever Increasing Usefulness Over the Years

\begin{tabular}{|c|c|c|c|c|c|c|c|}
\hline $\begin{array}{c}\text { All dasses of } \\
\text { Certificated Air Carriers }\end{array}$ & 1939 & 1949 & 1958 & $\begin{array}{c}\text { All classes of } \\
\text { Certificated Air Carriers }\end{array}$ & 1939 & 1949 & 1958 \\
\hline $\begin{array}{l}\text { Number of Airlines..... } \\
\text { Cities Sfrred (exclud- } \\
\text { ing Allaskan points) } \\
\text { Aircraft in Service... } \\
\text { Seats Available (Daily). } \\
\text { Cruising Speed of } \\
\text { Fastest Transport... } \\
\text { Number of People } \\
\text { Employed......... }\end{array}$ & $\begin{array}{c}23 \\
286 \\
347 \\
5,100 \\
220 \mathrm{mph} \\
13,300\end{array}$ & $\begin{array}{c}45 \\
638 \\
1,083 \\
35,900 \\
315 \mathrm{mph} \\
76,000\end{array}$ & $\begin{array}{c}55 \\
703 \\
1,900 \\
103,700 \\
590 \mathrm{mph} \\
146,000\end{array}$ & $\begin{array}{c}\text { Total Airline Payrolls. } \\
\text { U. S. Mail Ton Miles .. } \\
\text { Number of Passengers } \\
\text { Carried............... } \\
\text { Average Fare.......... } \\
\text { Ton Miles of Freight } \\
\text { Carried............. }\end{array}$ & $\mid \begin{array}{c}\$ 24,000,000 \\
8,610,000 \\
1,864,000 \\
5.62 \\
2,713,000^{1}\end{array}$ & $\left|\begin{array}{c}\$ 349,000,000 \\
61,144,000 \\
16,723,000 \\
6.23 \xi \\
112,500,000\end{array}\right|$ & $\begin{array}{c}\$ 950,000,000 \\
177,430,000 \\
49,075,000 \\
5.8 \xi \\
501,591,000\end{array}$ \\
\hline
\end{tabular}

1 Freight and Express combined.

2 Early figures for Alasks not available but in 1958 there were 268 points served.

${ }^{7}$ For a discussion of this, see Suspended Passenger Fare Increase Case, No. 8613, Order No. E-1r812, CAB, Sept. 25, 1957, pp. 17-29, particularly charts 1, 2, and 4 (a)-(d).

'See Interim Fare Increase Case, No. 9288, Order No. E-12203, CAB, Feb. 25, 1958, p. 7.

Id. at 5-6, and app. C.

${ }^{10}$ General Passenger Fare Investigation, No. 8008, Order No. E-I0279, CAB, May Io, 1956. 
increase was granted ${ }^{11}$ and surcharges for jet service have been authorized. ${ }^{12}$ Despite constantly improving service and higher costs, the average fare paid by the passenger for air transportation has not increased in the postwar period-partly because of the introduction of coach service in $1948^{13}$

In 1957 and 1958, the financial picture looked particularly bleak, and while the results for the end of 1958 and for 1959 have shown improvement, there is no clear indication that the airlines are out of the woods yet. ${ }^{13 a}$

These financial pressures have resulted in part from the demands of employee groups. As shown in appendix $\mathrm{A}$ at the end of this article, the increases in average pay of mechanics during the past twelve years have substantially exceeded increases in the Consumer Price Index plus an annual productivity factor, and this has not been passed on to the consumer. Recent settlements have brought the pay level of mechanics even higher. Similarly, as a result of negotiations recently concluded, a senior pilot's compensation may run up to $\$ 33,000$ per year, exclusive of substantial fringe benefits including, in some cases, more than two weeks' free time at home every month. ${ }^{14}$

"These, then, are salient factors presently affecting the labor relations of the airlines. Having them in mind will make more meaningful some of the aspects of the Railway Labor Act discussed in the next section.

\section{II}

\section{The Operation of the Railway Labor Act}

\section{A. Legislative Background}

The Railway Labor Act was passed in 1926 to regulate the labor relations of the railroads. ${ }^{15}$ It is developed from earlier legislation dating back to $1888 .{ }^{16}$ In I934, its

${ }^{11}$ Interim Fare Increase Case, No. 9288, Order No. E-12203, CAB, Feb. 25, 1958.

${ }^{12}$ See Additional Charges Proposed by American Airlines, Inc. for Boeing 707 Jet Aircraft, No. I0142, Order No. E-13395, CAB, Jan. 16, 1959, and id., Order No. E-13417, Jan. 22, 1959, in which the Board states that the extra charge is not for jet service as such, but for the "more deluxe type of service."

${ }^{-3}$ See note 6 supra. App. A contains an indication of the trend in revenue-mile yields since 1948 .

${ }^{132}$ In General Passenger Fare Investigation, No. 8008, Initial Decision, CAB, May 27, 1959, pp. 167, 177, Examiner Ralph L. Wiser concluded that "the domestic trunkline air-transport industry failed to carn" a fair return in 1957 and 1958 by any reasonable standard of consideration," and that "in' 1957 and 1958 , both yearly and 5-year averages of profits were well below a reasonable level."

14 See Sheehan, What's Eating the Airline Pilots?, Fortune, April 1959, pp. 122, 123. Historically, one reason for the high level of pilot compensation was the expectation that they would be compelled to retire at a comparatively early age. In Presidentiar Emergency Board No. 36, Repont II, I2 (r946), for example, it is stated that "Expert evidence indicates that the active flying life of an air-line pilot may extend up to 50 years. .. [While] flying careers may be longer than generally believed ... the chance of continuing beyond 50 is doubtful." That emergency board proceeding in volved problems in the transition from two to four-engine equipment in 1946. Before World War II, it was thought that pilots would have to end active flying even sooner. That has not proved to be the case in practice. At present, there are a number of airline pilots over 60; and, in fact, two adjustment bóards recently ruled that a carrier could not impose a compulsory retirement age of 60 on its pilots. An action for a declaratory judgment that such a ruling is erroneous and void has been commenced by Western Air Lines against the Air Line Pilots Association in the United States District Court for the Southern District of California.

${ }^{15} 44$ Stat. 577,45 U.S.C. $\$ \S I_{51-63}$ (I952). The constitutionality of the prohibition against inter- 
procedures for dealing with certain types of disputes were strengthened. ${ }^{17}$ The Act was made applicable to the airlines by the addition of title two in $19360^{18}$. There have been no statutory changes since then, other than an amendment in I95I authorizing union-shop agreements and the check-off of union dues. ${ }^{19}$

\section{B. Coverage}

The Act covers air and rail carriers in interstate commerce, ${ }^{20}$ including stateowned railroads ${ }^{21}$ and foreign carriers with employees based in the United States, ${ }^{22}$ whether the services performed are directly connected with transportation or not. ${ }^{23}$ It does not cover employees based in foreign countries. ${ }^{24}$ "Subordinate officials" are included in the definition of "employees." 25

ference with union organization was upheld in Texas \& New Orleans R.R. Co. v. Brotherhood of Railway \& Steamship Clerks, 28I U.S. 548, 570 (I930). Although the Act had the approval of representatives of both the railroads and the unions, House Comm. on Interstate and Foreign Commerce, Railway Labor Disputes, H.R. ReP. No. 328, 69th Cong., rst Sess. (r926), Donald Richberg and David Lilienthal, his associate, have been referred to as its draftsmen.

${ }^{10} 25$ Stat. 501 (1888); Erdman Act, 30 Stat. 424 (1898); Newlands Act, $3^{8}$ Stat. 103 (xgr3); Adamson Act, 39 Stat. 721 (19I6); General Order No. 8 (Feb. 21, 19I8); Transportation Act of 1920, 4I Stat. 469. These earlier statutes are summarized in National Mediation Board, Administration of the RaIlway Labor ACT BY the National Mediation BoARd, x934-1957, app. B (1958) [hereinafter cited as NMB REPORT]; and the circumstances of their passage, as well as the passage of Railway Labor Act, are described in Leonard A. Lecht, Experience UNDER RaILway Labor Legislation I4-46 (I955).

${ }^{17}{ }_{4} 8$ Stat. II 85,45 U.S.C. $\$$ I5I (1952). See LECHT, op. cit. supra note 16 , at 73 . The constitutionality of an enforceable duty to bargain was upheld in Virginian Ry. Co. v. System Federation No. 40,300 U.S. 515, 553, 557 (1937).

${ }^{18} \S \S 20 I-08,49$ Stat. II 89,45 U.S.C. $\$ \S$ I8I-88 (I952).

$20 \$ 2$, Eleventh, 64 Stat. 1238,45 U.S.C. $\$ 152$, Eleventh (1952). The check-off provision relates to "any periodic dues, initiation fees, and assessments (not including fines and penalties) uniformly required as a condition of acquiring or retaining membership." Railway Employees' Dep't v. Hanson, 35 U.S. 225 (1956), holds that the amendment is constitutional and that it pre-empts state right-to-work laws. In International Ass'n of Machinists v. Street, I08 S.E.2d 796 (Ga. I959), from which an appeal is pending to the United States Supreme Court, it was held that a union-shop agreement under the Railway Labor Act violated constitutional rights if the dues collected were used to foster programs and ideologies opposed by some of the employees.

${ }^{20} \S$ I, First, 49 Stat. IIgr (1936), 45 U.S.C. $\$$ I5I (1952).

${ }^{21}$ California v. Taylor, 353 U.S. 553 (1957).

${ }^{23}$ See Rutas Aereas Nacionales, S.A. v. Edwards, 244 F.2d 784 (D.C. Cir. 1957); Decker v. Linea LAeropostal Venezolana, 258 F.2d I53 (D.C. Cir. I958).

${ }^{33}$ See Biswanger v. Boyd, 40 L.R.R.M. 2267 (D.D.C. I957), and NMB Case Nos. C-2505 (1956) and R-332I (I959). But Northwest Airlines, Inc. v. Jackson, I85 F.2d 74 (8th Cir. 1950), cert. denied, 342 U.S. 8 I2 (I95I), holds that employees not engaged in transportation' activities are not within the overtime pay exemption for Railway Labor Act employees in $\S I_{3}(\mathrm{~b})(3)$ of the Fair Labor Standards Act. 52 Stat. 1067 (1938), as amended, 63 Stat. 917 (1949), 29 U.S.C. $\$ 213$ (1952). The NLRB follows a policy of not asserting jurisdiction in doubtful cases unless it has been declined by the NMB. See Northwest Airlines, Inc., 47 N.L.R.B. 498 (I943); Pan American World Airways, Inc., Guided Missiles Range Division, II5 N.L.R.B. 493 (1956); Interior Enterprises, Inc., I22 N.L.R.B. No. I80 (1959). See Fenton, The Taft-Harlley Act and the Airlines Industry, address before the Personnel Relations Conference of the Air Transport Association, Oct. I, 1958.

"Airline Dispatchers iAss'n v. NMB, I89 F.2d 685 (D.C. Cir. 195I), cert. denied, 342 U.S. 849 (195I); Air Line Stewards and Stewardesses Ass'n v. Northwest Airlines, Inc., 269 F.2d I70 (8th Cir. 1959); and Airline Stewards and Stewardesses Ass'n v. Trans World Airlines, Inc., I73 F. Supp. 369 (S.D.N.Y. I959) (appeal pending). For a summary of the NMB's views concerning jurisdictional problems, see NMB REPORT 6-8.

${ }^{25} \S$ I, Fifth, 44 Stat. 577 (1926), 45 U.S.C. $\$$ I5I (1952). In Case No. R-2107 (1949), the NMB held that mechanical foremen are "employees" for the purposes of the Act, but Case No. C-2783 (r959) 
Air and rail carriers may seek protection against secondary boycotts under section 8(b) (4) (A) of the National Labor Relations Act, ${ }^{20}$ but prior to the passage of the Labor Management Reporting and Disclosure Act of $1959{ }^{26 a}$ it was problematical whether relief would be afforded. ${ }^{20 b}$ One of the purposes of the new law is to make the secondary boycott prohibitions clearly applicable to such carriers and their employees. $^{27}$

\section{Representation}

The Railway Labor Act protects employees in the selection of bargaining representatives; ${ }^{28}$ and the National Mediation Board, charged with settling representation disputes, ${ }^{29}$ interprets this protection as requiring it to promote the organization of employees. ${ }^{30}$ One curious manifestation of this interpretation is that the NMB representation election ballots contain no space for a negative vote. ${ }^{31}$ Consequently, employees not wishing union representation must either not vote or vote an invalid ballot by marking "No Union" on it."

Before conducting an election, the NMB determines the system-wide "class or

indicates that such employees are not included within the scope of an airline mechanics certification. The application of the Act to middle management personnel is criticized in Dale \& Raimon, Management Unionism and Public Policy on the Railroads and the Airlines, II IND. \& LAB. Rez. Rev. 55 I (1958). By way of contrast, the National Labor Relations Act excludes "any individual employed as a supervisor." $\$ 2$ (3), 6I Stat. 138 (I947), 29 U.S.C. $\$ 152$ (I952).

${ }_{20} 49$ Stat. 452 (1935), 29 U.S.C. $\$ 158($ b) (4)(A) (I952). See Local Union No. 25, Teamsters v. New York, N.H., \& H. R.R. Co., 350 U.S. 155 (I956).

${ }^{202} 73$ Stat. 5I9, 29 U.S.C.A. $\$ \$ 401-531$ (Supp. 1959).

206 The NLRB took the position that $\$ 8(\mathrm{~b})(4)(A)$ did not protect carriers from secondary boycotts. See Local No. 1205, Teamsters, 122 N.L.R.B. No. 148 (1959). Some of the courts did not agree with this position, however, nor did the NLRB general counsel. See W. T. Smith Lumber Co. v. NLRB, 246 F.2d 129 (5th Cir. 1957); Knapp v. United Steelworkers of America, 38 CCH Lab. Cas. I 65,806 (D.C. Minn. 1959).

${ }_{27}$ Labor Management Reporting and Disclosure Act of $1959, \$ 704(\mathrm{a}), 73$ Stat. 525, 29 U.S.C.A. 5 158(b)(4)(A) (Supp. 1959), does this by changing "employer" to "person." See S. Rep. No. I87, 86th Cong., Ist Sess. (1959). Title VII of this Act, which amends the Labor Management Relations Act of $1947,6 \mathrm{I}$ Stat. 136 (codified in scattered sections of 29 U.S.C.), is otherwise inapplicable to Railway Labor Act industries, but the other 6 titles are. Those titles contain a "bill of rights" for union members; reporting requirements for employers, unions, and labor relations consultants; provisions relating to union trusteeships, elections, and fiduciary duties; and miscellaneous matters.

${ }^{28} \S 2$, Third and Fourth, 44 Stat. 577 (1926), 45 U.S.C. $\$ 152$ (1952).

${ }^{29}$ Ibid. Since that section refers to a representation dispute "among a carricr's employecs," the NMB takes the position that carriers may not institute or be a formal party in such proceedings, although it may "in its discretion hold a public hearing ... at which the carrier concerned is usually invited to present factual information." NMB REPORT 4, 19. As a consequence, no means is afforded whereby the employer can directly challenge the majority status of a union seeking to bargain or protect itself against jurisdictional disputes. Under the amended National Labor Relations Act $\$ 9$ (c), 6r Stat. 143 (1947), 29 U.S.C. $\$ 159$ (c) (1952), employers are expressly given the right to petition for an election. For criticism of the absence of a similar provision in the Railway Labor Act, see Dale \& Raimon, supra note 25, at 571.

${ }^{\text {so }}$ See NMB REPORT 15.

31 Id. at I9.

32 The NMB requires that a majority of the eligible employees cast valid ballots in order for a union to be certified as a bargaining agent. See $\$ 2$, Fourth, 44 Stat. 577 (1926), 45 U.S.C. $\$ 152$ (1952). Ballots marked "No Union" are considered void, so are not counted toward the majority of valid ballots required. See NMB Report I6-I8; NMB Case No. R-3273 (1958). 
craft" of employees to be represented. ${ }^{33}$ What constitutes a craft or class is a difficult question in some cases, ${ }^{34}$ and the Board has placed a narrow interpretation on its authority to make such determinations. ${ }^{35}$ Because of the class or craft criterion for the organization of bargaining units, a carrier may have to deal with more than half a dozen different unions having a variety of differing objectives. ${ }^{36}$

Once a bargaining agent has been designated by the Board (or recognized by the carrier without an election), disputes between the union and carrier fall into two categories, in the parlance which has developed under the Railway Labor Act. Controversies over rates of pay, rules, or working conditions in the negotiation of a new contract are referred to as "major" disputes; these are distinguished from "minor:" disputes, which involve employee grievances or the interpretation or application of an effective agreement. ${ }^{37}$ Consistent with its primary purpose of "avoid[ing] any interruption to commerce or to the operation of any carrier engaged therein" within the framework of collective bargaining, ${ }^{38}$ the Act has elaborate machinery for the settlement of both types of disputes, as described in the next two sections.

\section{Minor Disputes}

Minor disputes usually are processed through three steps and then, if unresolved, are submitted to an adjustment board for a "final and binding" award."

The National Railroad Adjustment Board processes railroad minor disputes. It is a permanent body of thirty-six members divided into four divisions. The railroads and the unions "national in scope" each designate half of the members. Each division has jurisdiction over disputes involving specified categories of employees. ${ }^{40}$ Although title two of the Act authorizes a National Air Transport Adjustment Board for air carriers, ${ }^{41}$ it has never been established. ${ }^{42}$ Instead, it is customary for the air carriers' working agreements to provide for system boards of adjustment having a similar jurisdiction. ${ }^{43}$ Such boards have representatives of both the carrier and union, but

$33 \S 2$, Ninth, 44 Stat. 577 (I926), 45 U.S.C. $\$ I_{52}$ (1952). (This also varies from the National Labor Relations Act, where an "appropriate" unit under $\$ 9,49$ Stat. 453 (I935), as amended, 29 U.S.C. $\S 159$ (b) (1952), may be an "employer unit, craft unit, plant unit, or subdivision thereof.") This section authorizes the NMB to "appoint a committee of three neutral persons who after hearings shall within ten days designate the employees who may participate in the election." This procedure was used for the first time when, on Nov. 17, 1959, the Board appointed such a committee in connection with the Air Line Pilats Association petition to represent "flight deck crew members" of United Air Lines. NMB File No. 2946. This proceeding is another branch of the dispute between the pilots' and the flight engineers' unions.

${ }^{34}$ See NMB REPORT 19-22.

${ }^{35}$ Id. at 25. See NMB Case No. R-207 (1937). See also note 25 supra.

${ }^{30}$ As one observer has said (in an unpublished speech), "The multiplicity of contracting parties in the airline industry has all the disadvantages but, so far as I can see, none of the attractiveness of a harem. There is constant turmoil not only between the airline and its polygamous flock but also between the jealous rivals themselves."

${ }^{87}$ See Elgin, Joliet \& Eastern Ry. Co. v. Burley, 325 U.S. 7II, 722-24 (I945).

${ }^{38} \S 2$ (I), 44 Stat. 577 (1926), 45 U.S.C. $\$ 151 a$ (1952).

${ }^{80} \S 3(\mathrm{~m}), 44$ Stat. 578 (1926), 45 U.S.C. $\$ 153$ (I952).

10 libid.

12 \$ 205, 49 Stat. IIgo (1936), 45 U.S.C. $\$$ I85 (1952).

"See NMB REPort 29.

1s $\S 204,49$ Stat. 1189 (1936), 45 U.S.C. $\S 184$ (1952). 
the disputes usually are settled by a neutral referee who is either agreed to by the parties or selected by the NMB. Neutrals chosen for the adjustment boards of air carriers function much like regular labor arbitrators. The NRAB, however, since it is a continuing body, has developed characteristics of its own. ${ }^{44}$

\section{E. Major Disputes}

As to major disputes, the parties first bargain without assistance following a thirty-day notice of opening on existing contracts. ${ }^{45}$ If an impasse results, the NMB steps in, either on its own motion or at the request of either party. ${ }^{48}$ Should agreement still not be reached, the Board proffers arbitration, ${ }^{47}$ and if that is refused (as it usually is), ${ }^{48}$ as a last resort the Board may (but need not) recommend the appointment of a presidential emergency board. ${ }^{49}$ The emergency board makes an investigation, perhaps attempting to mediate the dispute itself, and then reports to the President. The parties are required to maintain the status quo ${ }^{50}$ until thirty days have elapsed after the emergency board's report, following which the union may strike and the carrier may change conditions of employment and presumably hire replacements. Theoretically, the carrier also could resort to a lockout at that time, but as a practical matter-aside from competitive considerations-this is not feasible because of its obligations under unexpired contracts with other unions.

Major dispute proceedings often consume a great deal of time. The recent controversy between six air carriers and the International Association of Machinists is a case in point. ${ }^{51}$ The agreements with the IAM expired on October I, 1957. Approximately thirty days prior thereto the unions and companies exchanged proposals and began negotiating. Negotiations having proved fruitless, the services of

"For appraisals of the NRAB, sce Northrup \& Kahn, Railroad Grievance Machinery: A Critical Analysis, 5 IND. \& LAB. Rel. Rev. 365 (1952); Garrison, The National Railroad Adjustment Board: $A$ Unique Administrative Agency, 46 Y $\mathrm{ALE}$ I.J. 567 (1937).

${ }_{45} \S 6,44$ Stat. 582 (1926), 45 U.S.C. $\$ 156$ (1952).

$10 \$ 5,6,44$ Stat. $580-82$ (1926), 45 U.S.C. $\$$ I55-56 (1952).

17 $\$ .5,44$ Stat. 580,45 U.S.C. \$ 155 (1952).

${ }^{48}$ E.g., 24 NMB ANN. REP. 25 (r958) lists only one major dispute arbitration for the air transport industry in $\mathbf{1 9 5 7}$, and that did not involve the arbitration of an entire contract dispute. It originally was hoped that there would be "recourse to arbitration in practically every instance where the mediators cannot bring about an agreement." See testimony of Donald R. Richberg, in Hearings Before the Committee on Interstate and Foreign Commerce on H.R. 7180, Railioad Labor Disputes, 69th Cong., 1st Sess, 103 (1926). TWA and the stewardesses' union agreed in November 1959 to submit their major dispute to arbitrator David Cole.

${ }^{40}$ Under $\S$ Io, 44 Stat. 586 (1926), 45 U.S.C. $\S 160$ (1952), the NMB notifies the President only if the dispute, in its judgment, threatens "substantially to interrupt interstate commerce to a degrce such as to deprive any section of the country of essential transportation service," and the President then appoints the emergency board "in his discretion." During and after the ro8-day strike by the pilots against Western Air Lines in 1958 , there was considerable criticism of the NMB's failure to recommend the appointment of an emergency board.

${ }^{\text {to }} \S$ ro, 44 Stat. 586 (1926), 45 U.S.C. $\$ 60$ (1952), provides that "no change, except by agreement, shall be made by the parties to the controversy in the conditions out of which the dispute arose." Under $\$ 5,44$ Stat. 580 (1926), 45 U.S. C. $\$ 155$ (1952), the parties may make "no change . . . in the rates of pay, rules, or working conditions or established practices in effect prior to the time the dispute arose" during mediation or for 30 days thereafter.

52 The six airlines were Capital, Eastern, National, Northeast, Northwest, and Trans World. 
the NMB were invoked, and continued for several months. The Mediation Board then proffered arbitration, which was refused, and on February 27, 1958, the President created Emergency Board Number 122 by executive order. That Board first met on March II for organizational purposes. Hearings commenced April I5, $195^{8}$ and continued for a total of sixty days thereafter, closing on July 29 , I958.

The Board (comprised of Howard A. Johnson, retired chief justice of the Supreme Court of Montana, as Chairman; Dr. Paul N. Guthrie, professor of labor economics at the University of North Carolina; and Francis J. Robertson, an attorney from Washington, D.C.) heard at length representatives of the parties and expert witnesses. Seven thousand, one hundred and sixty-two pages of testimony were taken, and approximately 970 exhibits, containing some 5,000 pages, were received in evidence. Following the hearings, the Board met with the parties informally in an unsuccessful attempt to bring about a settlement. It then produced a report and recommendations on September ${ }^{5}$, I958. That report contained Iro printed pages. ${ }^{52}$

The union had sought more and the carriers, less, than the Emergency Board recommended. The carriers, nevertheless, announced that they would accept the recommendations, but the IAM said merely that it would consider them as a "basis for further negotiations." 53 Negotiations thereupon continued for thirty days, and a series of strikes followed.54 The ultimate settlements were substantially in excess of the Emergency Board's recommendations..$^{55}$

The question arises as to just what the President is supposed to do after receiving a report from an emergency board. When the Railway Labor Act was passed, a great deal of pious confidence in the salutary effect of public opinion was expressed. In fact, Donald Richberg, counsel to the railroad unions and chief draftsman of the Act, stated that because of public opinion, it would be difficult for the parties not to accept emergency board recommendations. ${ }^{56}$ In practice, however, such recommendations have not been the basis for settlement, but merely "a springboard from which [the unions] could obtain further concessions." 57 "For over a decade the significant collective bargaining developments have usually occurred after the report was issued and found unacceptable."

As the NMB observed in $1953:^{59}$

Means must be found to focus attention on the reports of Presidential emergency boards in such manner that they will afford the basis of settlements without further prolonged negotiations and threats of strike action, if not actual strikes. Otherwise, the role to be

is Presidential Emergency Board No. r22, Report (1958).

${ }^{53}$ N.Y. Times, Sept. 20, 1958, p. 38, col. 7 .

is Capital was struck 37 days; Eastern, 35 days; and Trans World, 16 days by the IAM. The strikes took place between Sept. 15, 1958 and the end of the year.

(5) The Emergency Board recommended an increase of approximately 23 cents per hour spread over 2 years, and the settlements were 44 cents over 3 years (the Northwest settlement was $4 \mathrm{I}$ cents).

${ }^{0}$ Hearings, supra note 48 , at 18 -x9.

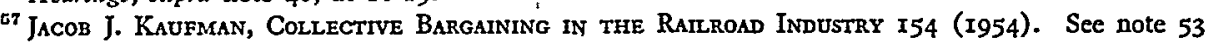
supra.

${ }^{68}$ LeCHT, op. cit. supra note $I 6$, at 6 .

50 19 NMB ANN. ReP. 7 (1953). 
played by such boards in the settlement of disputes in the transportation industry, as envisioned by labor, management and the Congress at the passage of this Act will lose its vitality and value.

At one time, the President could seize the carriers to prevent interruption to vital transportation services, ${ }^{60}$ but Youngstown Sheet \& Tube v. Sawyer ${ }^{81}$ cast doubt on his authority to do so in the absence of an emergency ${ }^{62}$ or specific congressional approval. ${ }^{62 a}$

\section{F. "Other" Disputes}

Several recent Railway Labor Act cases indicate that there are disputes which are neither major-since they do not involve rates of pay, rules or working conditions-nor minor-since they do not involve grievances or . . . the interpretation or application of agreements. ${ }^{63}$ Such disputes apparently refer to matters specifically reserved to management as "subject to its continuing authority to supervise and direct the manner of rendition of [an employee's] service."

Brotherhood of Railroad Trainmen v. New York Central R.R. Co. ${ }^{05}$ holds that a controversy concerning the closing of railroad yards in Toledo falls into the "other" dispute category. The railroad, therefore, was not obligated to process it as a grievance or to bargain about closing the yards. ${ }^{66}$ Moreover, as it was not considered a "labor dispute" under the Norris-LaGuardia Act, ${ }^{67}$ the federal court was not ousted by that act of jurisdiction to issue an injunction. ${ }^{68}$

${ }^{00}$ See In re Debs, 156 U.S. 564 (1895).

${ }^{81} 343$ U.S. 579 (1952).

${ }^{69}$ A 1916 statute gives the President authority in time of war to "take possession of all or any part of any system of transportation to transport troops, war material, and equipment, or for other purposes related to the emergency." 39 Stat. 645, as amended, $70 \mathrm{~A}$ Stat. 266,587 (1956), 10 U.S.C. $\$ \$ 4742,9742$ (Supp. V, 1958). See United States v. Brotherhood of Locomotive Engineers, 79 F. Supp. 485 (D.D.C.), cert. denied, 335 U.S. 867 (1948), vacated and remanded for mootness, 174 F.2d 160 (D.C. Cir.), cert. denied, 338 U.S. 872 (1949); United States v. Switchmen's Union of North Amcrica, 97 F. Supp. 97 (W.D.N.Y. x950).

${ }^{62 a}$ S. 80, 86th Cong., Ist Sess. (I959), introduced by Sen. Holland, of Florida, would have authorized the President to appoint a board of arbitrators for threatened airline strikes. The board could make binding awards on the issues in dispute, and strikes or lockouts would be prohibited. This bill has not been enacted.

${ }^{\circ 3}$ See note 37 supra.

6s $\S$ I, Fifth and 20I, 44 Stat. 577 (1926), 49 Stat. 1191 (1936), 45 U.S.C. \$\$ I5I, I81 (1952).

${ }^{05} 246$ F.2d 114 (6th Cir. I957), cert. denied, 355 U.S. 877 (1958).

${ }^{08} 246$ F.2d at 118 . Cf. Norfolk \& Portsmouth Belt Line Ry. Co. v. Brotherhood of Railroad Trainmen, 248 F.2d 34 (4th Cir. 1957), cert. denied, 355 U.S. 91 4 (1958), where the issue was framed as a minor dispute, since the carrier had elected to treat it as such by instituting adjustment board proceedings.

${ }^{67} 47$ Stat. 70 (1932), 29 U.S.C. $\S$ ror (1952).

${ }^{68}$ An additional question considered by the court was whether there was any basis for federal jurisdiction over the subject matter under $\S 1337$ of the Judicial Code, 62 Stat. 931 (1948), 28 U.S.C. $\$ 1337$ (I952), since no specific provisions of the Railway Labor Act were involved. Following Toledo, Pcoria \& Western Ry. v. Brotherhood of Railroad Trainmen, 132 F.2d 265 (7th Cir. 1942), rev'd on other grounds, 32 I U.S. 50 (1944), the court held (Judge, now Justice, Stewart dissenting) that its jurisdiction was based on the threatened interference with the common carrier's federal right and duty to provide facilities for interstate commerce. 246 F.2d at 122 . 
And in Chicago \& North Western Ry. Co. v. Order of Railroad Telegraphers, ${ }^{69}$ the Court of Appeals for the Seventh Circuit enjoined a strike over a carrier's "central agency plan," which resulted in the laying off of employees, on the ground that the union could not force the carrier to agree not to abolish positions without its consent. Like the "Toledo Yard" case discussed above, the Chicago \& North Western case involves essentially a featherbedding situation ("many station agents were receiving a full day's pay for twelve to thirty minutes' work"). While proposals concerning stabilization of employment such as severance pay, supplemental unemployment compensation benefits, and guaranteed employment might be legitimate objectives of collective bargaining, the court distinguished them from the situation before it as not vesting "indefinite retroactive veto power over abolition of positions [but] are expressly limited to prospective periods of short duration." The court went on to say: $:^{70}$

It appears clear that the effect of the Union's proposal, if accepted, would place in its hands the power to prevent any undertaking by North Western to meet competition by modernizing its operations in the light of technological development, and fulfilling its obligation of operating efficiently and economically for the benefit of itself, its employees, and the public. Ultimately the Union could even bring about a situation where the railroad itself might be forced out of business or so crippled financially that all employees, including the Union's members, would suffer. This contract proposal, if accepted, would · enable the Union to control the pace of North Western's compliance with the Commission orders aforesaid.

The proposed contract change in the case before us represents an attempt to usurp legitimate managerial prerogative in the exercise of business judgment with respect to the most economical and efficient conduct of its operations. It is perhaps significant that on oral argument, counsel for the Union expressed the opinion that a demand for veto over discontinuing trains, while less reasonable than that proposed here, would constitute a bargainable issue under the Railway Labor Act.

....

[t] he fact that other carriers may have submitted to unlawful demands does not change the character of such demands. A carrier may not escape its obligations in bargaining them away.

The court in the Chicago \& North Western case relied in part upon the distinction made by the Supreme Court in NLRB v. Borg-Warner ${ }^{71}$ between subjects of mandatory and permissive bargaining. Although the Borg-Warner case was decided under the National Labor Relations Act, both acts impose the duty to bargain upon the parties. ${ }^{72}$

${ }^{00} 264$ F.2d 254 (7th Cir.), cert. granted, 36I U.S. 809 (x959).

${ }^{30}$ Id. at $258-59$.

71356 U.S. 342 (1958). There the Court held that the employer's insistence that provisions for a strike ballot and for recognition of the local rather than the international be written in the agreement amounted to a refusal to bargain, since those matters were outside the scope of mandatory bargaining.

${ }^{75}$ Virginia Ry. Co. v. System Federation No. 40, 300 U.S. 515 (1937), is the leading case holding that there is an enforceable duty to bargain under the Railway Labor Act. 9 (a) (5) and $8($ b) (3) of the National Labor Relations Act make it an unfair labor practice for employers or unions to refuse to 
Other union demands which might fall within the "other" dispute category are those concerning "the type of product to be produced, the location of plants, the installation of new machinery and equipment," groups of employees. ${ }^{74}$ Demands relating to supervisory personnel (other than the "subordinate officials" specified in section one, Fifth) also may not require bargaining. ${ }^{\mathrm{TJ}}$

It is not clear whether a union can insist on demands giving rise to jurisdictional disputes affecting the jobs of other groups of employees. General Committee of Adjustments v. Missouri-Kansas-Texas $R . R .^{76}$ suggests that the federal courts have no jurisdiction over such matters because they are solely within the province of the NMB. ${ }^{77}$ In that case, however, the NMB had mediated the challenged agreement, and the result might have been different if it had not participated ${ }^{78}$ Otherwise, the holding seems inconsistent in principle with the cases cited above ${ }^{70}$ and Virginian Ry. Co.v. System Federation No. $40 .^{80}$

bargain. 49 Stat. 452 (1935), as amended, 6I Stat. 140 (1947), 29 U.S.C. $\$ 158$ (1952). Section 8(d) defines the scope of the duty to bargain as including "wages, hours, and other terms and conditions of employment." 49 Stat. 452 (1935), as amended, 6r Stat. 140 (1947), 29 U.S.C. \$158(d) (1952). Since the duty under the Railway Labor Act relates to "rates of pay, rules and working conditions," $\$ 2$, First, 44 Stat. 577 (1926), 45 U.S.C. $\$$ I5I (1952), it has been suggested that the bargaining duty under that Act has a narrower scope than the duty under the National Labor Relations Act. See Inland Steel Co. v. NLRB, I70 F.2d 247, 254 (7th Cir. 1948), cert. denied, 336 U.S. 960 (1949). On the general subject, see Cox, The Duty to Bargain in Good Faith, 7x Harv. L. Rev. I 401 (1958).

${ }^{73}$ Norfolk \& Portsmouth Belt Line Ry. Co. v. Brotherhood of Railroad Trainmen, 248 F.2d 34, 41 (4th Cir. 1957), cert. denied, 355 U.S. 914 (1958).

${ }^{7 t}$ See Brotherhood of Railroad Trainmen v. Howard, 343 U.S. 768 (1952); Graham v. Brotherhood of L.F. \& E., 338 U.S. 232 (1949).

${ }^{75}$ Cf. NLRB v. Retail Clerks, 2II F.2d 759 (9th Cir.), cert. denied, 348 U.S. 839 (1954); Ohio Power Co. v. NLRB, I76 F.2d 385 (6th Cir.), cert. denied, 338 U.S. 899 (1949); Safeway Stores, Inc. v. Retail Clerks, 4I Cal. 2d 567, 26r P.2d 72I (1953); Kerkemeyer v. Midkiff, 299 S.W.2d 409 (Mo. 1957).

7a 320 U.S. 323 (I943).

77 Perhaps of some significance is the fact that the $M-K-T$ case was decided the same day (and the opinion written by the same Justice (Douglas)) as Switchmen's Union of North America v. NMB, 320 U.S. 297 (1943), in which the Court held that no appeal may be taken from NMB certifications. The certification' of a union would seem to be different from the Board's mediation of an agreement, however, which was involved in the $M-K-T$ case. Curiously, Slocum v. Delaware, L. \& W. Ry. Co., 339 U.S. 239 (1950), also denies relief, but on the ground that the adjustment board (rather than the NMB) has cxclusive jurisdiction over jurisdictional disputes. In the Sloctm case, however, the issue arose as a minor dispute involving a determination of the work covered in the labor agreements. As should be readily apparent from their form of organization, adjustment boards are not capable of dealing satisfactorily with disputes between a carrier and two different unions over the same matter. See Union R.R. Co. v. NRAB, I70 F. Supp. 28I (N.D. Ill. I958), for an example of the difficult problems created when solution to jurisdictional disputes is sought through adjustment boards. Experience has by this time made it clcar that as a practical matter, there is no administrative remedy under the Railway Labor Act which protects carriers (or interstate commerce) from jurisdictional disputes-as there is for other industries under the National Labor Relations Act. See also Rolfes v. Dwellingham, I98 F.2d 591 (8th Cir. 1952).

${ }_{78}^{78}$ Cf. Texlite, Inc., $x 19$ N.L.R.B. 1792 (1958), enforced, 266 F.2d 349 (5th Cir. 1959).

${ }^{79}$ See note 75 supra.

${ }^{80} 300$ U.S. 515 (1937). This case holds the duty to bargain with the bargaining agent designated under $\$ 2$, Ninth, 44 Stat. 577 (I926), 45 U.S.C. $\$ 152$ (1952), to be judicially enforceable. That section "imposes the affirmative duty to treat only with the true representative, and hence the negative duty to treat with no other." 300 U.S. at 548 . (Emphasis added.) Cf. Whitehouse v. Illinois Cent. Ry. Co., 349 U.S. 366 (r955). Treating jurisdictional demands as outside the area of requircd bargaining would seem appropriate, especially in view of the fact that carriers have not been permitted to institute $\$ 2$, 
Since the Railway Labor Act contains no procedures for the settlement of "other" disputes, the courts are primarily responsible for resolving the legal problems which may arise. The next section deals with the role of the courts under other provisions of the Railway Labor Act.

\section{G. The Role of the Courts}

The most obvious role of the courts concerns those matters for which jurisdiction is specifically conferred by the Railway Labor Act: penalties for noncompliance with provisions giving employees the right to organize without interference and prohibiting, carriers from unilaterally changing rates of pay, rules, or working conditions except as provided in the $A c t ;{ }^{81}$ enforcement of adjustment board awards; ${ }^{82}$ and supervision of arbitration proceedings. ${ }^{83}$

Unlike the National Labor Relations Act, the Railway Labor Act authorizes no administrative body to undertake enforcement proceedings; the parties must commence their own actions to enforce rights under adjustment board awards or NMB certifications. ${ }^{84}$ Private lawsuits in the federal courts, therefore, have assumed an important role in enforcing rights and duties under the $A c t,{ }^{85}$ and it has been established that equitable relief is available in the federal courts in such cases, despite the anti-injunction provisions of the Norris-LaGuardia Act. ${ }^{\mathbf{8 6}}$

Ninth proceedings. If bargaining is not required on such demands, the union would then have to go to the NMB for a $\S 2$, Ninth determination. It seems obviously in the public interest to have such matters settled by administrative determination rather than by resort to economic warfare, and this is consistent with the Railway Labor Act's objective of minimizing interruptions to commerce. $\$ 2$, First, 44 Stat. 577 (1926), 45 U.S.C. $\$ 152$ (1952). Although the conflict between the pilots and the flight engineers has been the most acute jurisdictional dispute during the past two years, jurisdictional disputes are a continuing general problem for the airlines.

${ }^{B 1} \S 2$, Tenth, 44 Stat. 577 (1926), 45 U.S.C. $\$ 152$ (1952).

$89 \$ 3$, First (p), 44 Stat. 578 (I926), 45 U.S.C. $\$ 153$ (I952). If the adjustment board has not made an enforceable order, however, there can be no judicial enforcement. See Bates v. Northwest Airlines, Inc., I7I F. Supp. 273 (D.C. Minn. 1959). This section of the Act gives United States district courts jurisdiction in suits by employees to enforce adjustment board awards. (Carriers are niot given a corollary right of enforcement.) In such actions, the findings and order of the adjustment board are "prima facie evidence of the facts therein stated." $\$ 3$, First $(\mathrm{m})$, however, makes such a determination "final and binding" upon the parties, "except insofar as [it] shall contain a money award." The Supreme Court has held that these provisions make an adjustment board award "final and binding" if a money claim of an employee is denied, but subject to judicial review if such a claim is granted. In Union Pacific Ry. Co. v. Price, 37 CCH Lab. Cas. 65,559 (r959), Mr. Justice Brennan, speaking for the Court, observed: "The disparity in judicial review of Adjustment Board orders, if it can be said to be unfair at all, was explicitly created by Congress, and it is for Congress to say whether it ought to be removed."

$\S 201,49$ Stat. II89 (1936), 45 U.S.C. $\$$ I8I (1952), makes $\$ 3$ inapplicable to air carriers, but $\S 204,49$ Stat. 1189 (1936), 45 U.S.C. $\$ 184$ (1952), requires such carriers to establish adjustment boards having jurisdiction "not exceeding" the jurisdiction of the railroad boards.

83 $\$ \S 7,8,9,44$ Stat. $582-85$ (I926), 45 U.S.C. $\$ \$$ I57, 158 (I952).

st See, e.g., Switchmen's Union of North America v. NMB, 320 U.S. 297 (I943).

${ }^{85}$ The United States district courts have general jurisdiction under $\$ \$ 1331$ and 1337 of the Judicial Code, 62 Stat. 930 (1948), 28 U.S.C. $\$ \$ 1331$, 1337 (1952). Jurisdiction apparently also lies in the state courts in some matters. Cf. Manion v. Kansas City Terminal Ry. Co., 353 U.S. 927 (1957); National Airlines, Inc., v. Metcalf, $38 \mathrm{CCH}$ Lab. Cas. \65,737 (Fla. D.C. App. I959).

${ }^{80}$ See Virginian Ry. Co. v. System Federal No. 40, 300 U.S. 515 (1937); Brotherhood of Railroad Trainmen v. Howard, 343 U.S. 768 (1952); Brotherhood of Railroad Trainmen v. Chicago River \& Indiana Ry. Co., 353 U.S. 30 (I957). 
Equitable relief has been granted to prevent interference or coercion in the selection of bargaining representatives; ${ }^{87}$ to enforce the duty to bargain with certified representatives; ${ }^{88}$ to prevent discrimination in the representation of employees; ${ }^{80}$ to prevent strikes over minor disputes; ${ }^{90}$ and to prevent strikes during the completion of the major dispute procedures. $^{01}$ Declaratory relief might also be available, ${ }^{02}$ as well as damages. ${ }^{93}$ Prior resort to the appropriate administrative agency is a neces-

${ }^{87}$ Texas \& New Orleans R.R. v. Brotherhood of Railway \& Steamship Clerks, 28r U.S. 548 (r930).

${ }^{88}$ Virginian Ry. Co. v. System Federation No. 40, 300 U,S. 515 (1937).

${ }^{80}$ See the discussion in the next paragraph.

${ }^{80}$ Brotherhood of Railroad Trainmen v. Chicago River \& Indiana Ry. Co., 353 U.S. 30 (1957). As indicated above, the adjustment board is the agency established under the Railway Labor Act for the settlement of minor disputes. It has been held, therefore, that an injunction to restrain a strike over a dispute coming within the jurisdiction of an adjustment board should not be conditioned upon restoration by the carrier of the status quo ante if the dispute concerns the carrier's right to take unilateral action. Otherwise, the court, rather than the adjustment board, would be, in effect, passing on the merits of the dispute. See Missouri-Kansas-Texas Ry. Co. v. Brotherhood of Locomotive Engineers, 266 F.2d 335 (5th Cir. 1959), cert. granted, 36I U.S. 8ro (1959); Baltimore \& Ohio Ry. Co. v. 'Transport Workers' Union, 38 CCH Lab. Cas. I 65,8I9 (2d Cir. 1959); Pennsylvania R.R. Co. v. Transport Workers' Union, 38 CCH Lab. Cas. I 65,850 (E.D. Pa. 1959).

${ }^{91}$ American Airlines, Inc. v. Air Line Pilots Association, 169 F. Supp. 777, (S.D.N.Y. 1958); Trans World Airlines, Inc. v. Air Line Pilots Association (W.D. Me. 1959); Railway Express Agency, Inc. v. Teamsters (S.D.N.Y. 1957). Cf. Butte, Anaconda \& P. Ry. Co. v. Brotherhood of L.F. \& E., 268 F.2d 54 (9th Cir. 1959). In Norfolk \& Portsmouth Belt Line Ry. Co. v. Brotherhood of Railroad Trainmen, 248 F.2d 34, 46 (4th Cir. 1957), cert. denied, 355 U.S. 914 (1958), the union alternatively took the position that a major dispute was involved. Although minor disputes may be processed through to a "final and binding" award, major disputes must ultimately be settled by agreement of the parties (or by voluntary arbitration). Injunctive relief in major disputes, therefore, goes only to preserving the status quo during completion of statutory procedures and cooling-off periods, so that the parties may thercby be induced to agree without resorting to economic "self-help." See Elgin, Joliet \& Eastern Ry. Co. v. Burley, 325 U.S. 7II, 725 (1945). In Chicago \& North Western Ry. Co. v. Order of Railroad Telcgraphers, 36 CCH Lab. Cas. I 65,103 (N.D. Ill. 1958), rev'd on other grounds, 264 F.2d 254 (7th Cir.), cert. granted, 36I U.S. 809 (1959), the question arose as to whether the court could preserve the status quo by restraining a strike in a major dispute only for the cooling-off period following the NMB's proffer of arbitration, or whether a new status quo period was started later when the Board had intervened in an emergency effort to avert a strike. The court held that the emergency mediation gave rise to a new status quo period.

9a See Akron, Canton \& Youngstown Ry. Co. v. Barnes, 215 F.2d 423 (7th Cir.), judgment vacated and remanded on representation of mootness by respondent's counsel, 348 U.S. 893 (I954); Felter v. Southern Pacific Co., 358 U.S. 812 (1959). Declaratory relief has been denied on the ground that an administrative agency has exclusive jurisdiction over the question involved. See General Committee of Adjustment v. Missouri-Kansas-Texas R.R., 320 U.S. 323 (1943); Slocum v. Delaware, L. \& W. Ry. Co., 339 U.S. 239 ( 1950 ). Declaratory relief apparently also would not be available where there is a possibility that the problem will be solved by an administrative determination or by an enforcement procecding. See Washington Terminal Co. v. Boswell, I24 F.2d 235 (D.C. Cir. 1941), aff'd by an equally divided court, 3 I9 U.S. 732 (1943). Cf. Whitehouse'v. Illinois Cent. Ry. Co., 349 U.S. 366 (1955). The courts perhaps have been too sparing in the granting of declaratory relicf in such cases. As Judge Dimock said in Prudential Ins. Co. v. Insurance Agents Int. Union, I69 F. Supp. 534, 536 (S.D.N.Y. 1959):

"It seems to me that courts in exercising their discretion in declaratory judgment cases ought to be particularly liberal where labor relations are involved. The most serious defect in the current trial-by-battle method of resolving disagreements between labor and management is that the method has no natural tendency to attain a reasonable result. The courts should welcome the opportunity to act in every case where, under the law, they can substitute a decision based on reason for one based upon the relative might of the contenders."

${ }^{93}$ See Louisville \& Nashville Ry. Co. v. Brown, 252 F.2d I49 (5th Cir.), cert. denied, 356 U.S. 949 (I958) (under state law). 
sary preliminary to obtaining judicial relief. ${ }^{94}$ Venue lies wherever the labor organization or carrier sued has a place of business. ${ }^{95}$

The courts have asserted jurisdiction to prevent racial discrimination, even though the Railway Labor Act does not expressly confer jurisdiction or require a union not to discriminate. ${ }^{98}$ The theory of such relief is that the duty not to discriminate is implicit in the privileges which the Act confers upon unions ${ }^{97}$ and that the courts should assert jurisdiction because of the lack of an administrative remedy. ${ }^{98}$ The Supreme Court has not decided whether the rule in these cases applies to other than racial discrimination, ${ }^{99}$ and the lower courts are divided on the question. ${ }^{100}$

An exceedingly complex body of law has developed concerning adjustment board proceedings. The most challenging current problems have to do with (a) the extent to which union discrimination (racial or otherwise) is a basis for judicial review or reversal of adjustment board awards, ${ }^{101}$ and (b) the availability of a state cause of

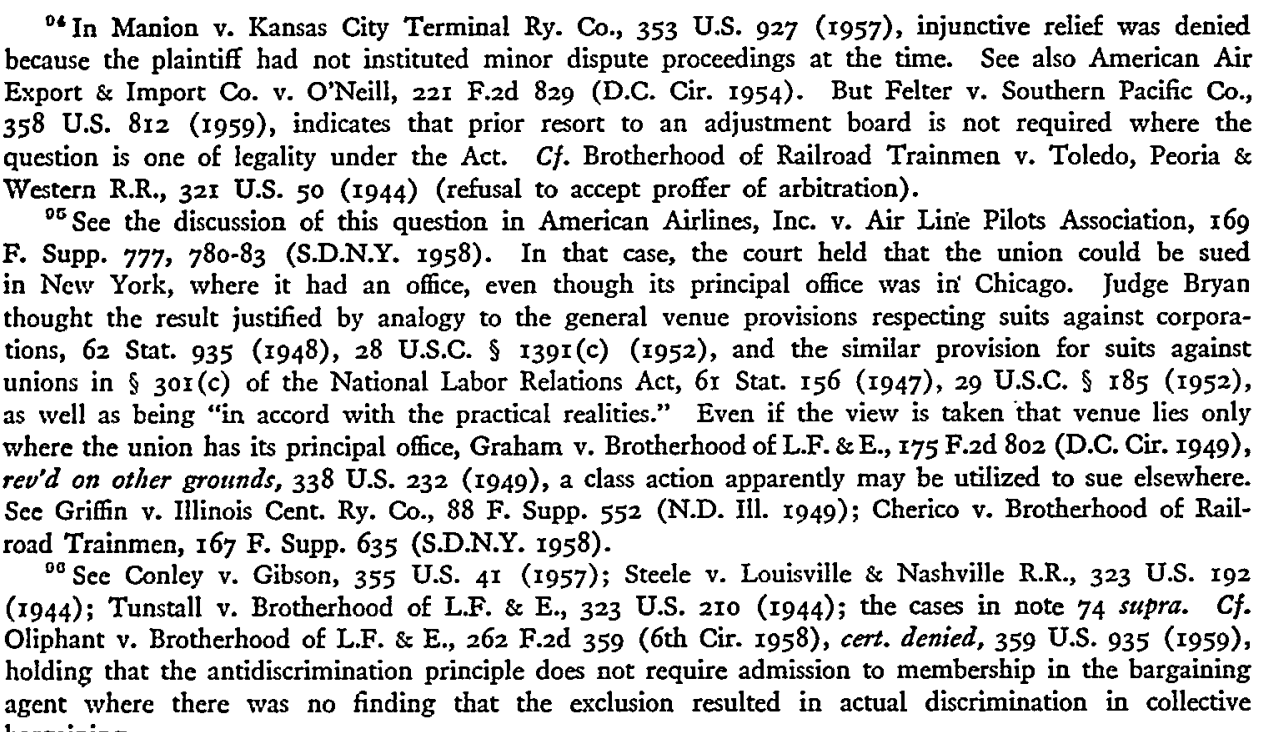
bargaining.

${ }^{07}$ Steele v. Louisville \& Nashville R.R., 323 U.S. $192,202-03$ (1944).

${ }^{\circ 8}$ Id. at 207.

${ }^{00}$ There is dictum in Ford Motor Co. v. Huffman, 345 U.S. 330, 337 (I953), suggesting that the principle has general applicability.

${ }^{100}$ Limited to racial discrimination: Colbert v. Brotherhood of Railroad Trainmen, 206 F.2d 9 (9th Cir. I953), cert. denied, 346 U.S. 93I (I954); Spires v. Southern Ry. Co., 204 F.2d 453 (4th Cir. 1953); Alabaugh v. Baltimore \& Ohio Ry. Co., 222 F.2d 86I (4th Cir. I955); Brock v. Brotherhood of Sleeping Car Porters, I29 F. Supp. 849 (W.D. La. x955). Not limited to racial discrimination: Cunningham v. Erie R.R. Co., 266 F.2d 4 I I (2d Cir. 1959); Mount v. Brotherhood of Locomotive Engineers, 226 F.2d 604 (6th Cir. 1955), cert. denied, 350 U.S. 967 (1956); Hargrove v. Brotherhood of Locomotive Engineers, I 6 F. Supp. 3 (D.D.C. I953); Brady v. Trans World Airlines, Inc., I74 F. Supp. 360 (D. Del. I959); Cherico v. Brotherhood of Railroad Trainmen, rx6 F. Supp. 635 (S.D.N.Y. I958). See also Rose, The Railway Labor Act and Jurisdiction of the Courts, 8 LaB. L.J. 9 (I957); Wellington, Union Democracy and Fair Representation, 67 YALE L.J. 1327 (1958); Cox, The Role of Law in Preserving Union Democracy, 72 Harv. L. Rev. 609 (1959); Cox, The Duty of Fair Representation, 2 Vill. L. Rev. I5I (1957).

${ }^{101}$ The doctrine was applied in Brady v. Trans World Airlines, Inc., r67 F. Supp. 469 (D. Del. 1958), as a basis for asserting juriscliction to review the award of a system board of adjustment where the union 
action for damages as an alternative remedy. ${ }^{102}$ Without attempting to discuss in detail these and related questions, it is enough to recognize that extreme complexity exists where there should be great simplicity, and consideration of amendatory legislation would appear to be warranted. As one exasperated judge remarked recently: ${ }^{103}$

Whereas the discharged employee should be guided by simple procedures geared to the sensitivities of his hardship, in reality he has been subjected to the rigors of a guessing game. The difficulty is that the decision of the Supreme Court in Moore and its holding in Koppal are, when served, barely digestible in the same system. Beyond that, it may be asked whether the law has removed itself from the arena of common sense by adopting in the upper reaches an unrealistic approach. To put the Socratic question, does the employee who has been discharged, being thus of an uneven mind-hounded by the realization of loss of job and support for his family for an indefinite period; overwhelmed by the bigness of Organization-Union, Carrier-seemingly, and even actually, banded against him; pressured by the increasing awareness he has so little time to act to seek job restoration; and induced by the thought the Adjustment Board is the quickest, and even sole, means of doing so-grasp for relief almost blindly ignorant in most cases of his legal position? In any event, if indeed, a choice must be made, is that the selective and measured act for which he $1 \mathrm{~s}$ later to be judged and refused admittance in the court house door?

One other question of general interest is the extent to which the Railway Labor Act pre-empts substantive provisions of state law. Since the Railway Labor Act contains no schedule of unfair labor practices such as that contained in the National Labor Relations Act, ${ }^{104}$ it might seem that greater latitude exists for the application of state labor policy. ${ }^{105}$ In Teamsters v. New York, New Haven \& Hartford R.R., ${ }^{100}$

members of the board did not support the discharged employee's contention. In Bohannon v. Reading Co., I68 F. Supp. 662 (E.D. Pa. 1958), it was assumed that Conley v. Gibson, 355 U.S. 41 (1957), cstablishes a federal cause of action for "hostile discrimination" by a union in the processing of gricvances. Two other cases hold that adjustment board awards are inherently unfair and subject to judicial review when the union members and representatives are antagonistic to the position of the grieving employec. Sec Edwards v. Capital Air Lines, I76 F.2d 755 (D.C. Cir.), cert. denied, 338 U.S. 885 (I949); Rychlik v. Pennsylvania R.R., 229 F.2d I7I (2d Cir. I956), rev'd on other grounds, 352 U.S. 480 (1957). Contra, Pigott v. Detroit, Toledo \& Ironton Ry. Co., 22I F.2d 766 (6th Cir.), cert. denied, 350 U.S. 833 (1955). Cf. Bower v. Eastern Airlines, Inc., 214 F.2d 623 (3d Cir.), cert. denied, 348 U.S. 87 (1954).

${ }^{109}$ There may be a state cause of action for discharge as an alternative to an adjustment board proceeding. Moore v. Illinois Cent. Ry. Co., 3I2 U.S. 630 (I94I). If state law requires the prior exhaustion of administrative Iemedies, however, the employee must comply with it by first sceking rclicf before the appropriate adjustment board. Transcontinental \& Western Air, Inc. v. Koppal, 345 U.S. 653 (1953). But if, in such a proceeding, reinstatement or recomputation of earnings is sought, or seniority rights are asserted, the adjustment board award is "final and binding," the board has exclusive primary jurisdiction, and there is no independent cause of action. Slocum v. Delawarc, L. \& W. R. Co., 339 U.S. 239 (1950); Pennsylvania R.R. Co. v. Day, 37 CCH Lab. Cas. 165,560 (U.S. Sup. Ct. r959); Order of Railway Conductors v. Southern Ry. Co., 339 U.S. 255 (I950); Rose v. Great Northern Ry. Co., 37 CCH Lab. Cas. 165,571 (8th Cir. x959); Majors v. Thompson, 235 F.2d 449 (5th Cir. 1956). The jurisdiction of the federal courts in discharge damage cases is based upon diversity of citizenship. Stack v. New York Cent. Ry. Co., 258 F.2d 739 (2d Cir. I958).

${ }^{103}$ Brady v. Trans World Airlines, Inc., 156 F. Supp. 82, 87 (D. Del. 1957). (Footnotes omittcd.)

${ }^{204} \S 8(\mathrm{a})$ and (b), 49 Stat. 452 (1935), as amended, 29 U.S.C. $\$ 15^{8}$ (a), (b) (1952).

${ }^{105}$ See, e.g., Louisville \& Nashville R.R. v. Brown, 252 F.2d I 49 (5th Cir.), cert. denied, 356 U.S. 949 (1958). See generally, Note, State Jurisdiction Over Torts Arising from Federally Cognizable Labor Disputes, 68 YALE L. J. 308 (1958).

${ }^{100} 350$ U.S. I55 (1956). 
however, it was held that state law was pre-empted in the field of secondary boycotts because of the protection in that field afforded to a railroad by the National Labor Relations Act.

\section{III}

\section{The Mutual AId Pact}

On October 20, 1958, six air carriers-American Airlines, Capital Airlines, Eastern Air Lines, Pan American World Airways, Trans World Airlines, and United Air Lines entered into what has been referred to as a "mutual aid pact."107

The agreement (which any certificated air carrier may join merely by signing and filing a copy with the $\mathrm{CAB}$ ) obligates each party "to pay over to the party suffering [a] strike an amount equal to its increased revenues attributable to the strike during the term thereof, less applicable added direct expense." The struck party agrees "to provide the public with information concerning all air services rendered by the other parties, and to direct to them as much of the traffic normally carried by the party suffering such a strike as possible, all as the best interests of the members of the public may require." 108

Those obligations arise, however, only if a strike resulting in a shutdown of flight operations (a) is called "for reasons which include the enforcement of demands in excess of or opposed to the recommendations of a [presidential emergency board] and applicable to [the struck] party," or (b) is called "before the employees on strike ... have exhausted the procedures of the Railway Labor Act," or (c) "is otherwise unlawful."109

The agreement became effective immediately, but provided for filing with the $\mathrm{CAB}$ and termination if disapproved by the Board. ${ }^{110}$ Otherwise the agreement was to terminate on October 20, I959, unless renewed. ${ }^{111}$

After the agreement had been filed with the CAB, January 14, 1959 was set as the date for oral argument, and the carriers and unions were invited to participate.

${ }^{107}$ Agreement CAB No. 12633 (1958) [hereinafter cited as Agreement].

${ }^{108}$ Id. $\$ \$ \mathrm{I}, 2,3$.

${ }^{100}$ Id. $\$ \mathrm{I}$.

${ }^{110} \S 412$ of the Federal Aviation Act of 1958,72 Stat. 770, 49 U.S.C.A. $\S 1382$ (Supp. I959), which carries over the provisions of $\S 4 \mathrm{I2}$ of the Civil Aeronautics Act of 1938, requires that agreements between carriers affecting air transportation and relating to various matters be filed with the CAB. The Board is then required to approve such agreement if it finds it not to be adverse to the public interest or in violation of the Act. The standards to be applied by the Board in considering the public interest are set forth in $\S 102$ of the Act. 72 Stat. 740, 49 U.S.C.A. $\S 1302$ (Supp. 1959). Such approval exempts the agreement from the antitrust laws. $\$ 414,72$ Stat. 770,49 U.S.C.A. $\$ 1384$ (Supp. 1959). The Act makes the holding of a certificate of public convenience and necessity by an airline subject to compliance with the Railway Labor Act. $\$ 40 I(I), 72$ Stat. 754, 49 U.S.C.A. $\$ 1371$ (Supp. 1959). The most nearly similar proceeding was in 1947, when the Board approved an air carriers' agreement to establish an agency to conduct labor negotiations. See Airline Negotiating Conference, 8 C.A.B. 354 (I947). The conference subsequently was abandoned by the airlines. It has been held that consideration of general labor management policies is outside the scope of the Board's authority in administering the mail pay program under $\S 406$ of the Act. See American Overseas Airlines v. CAB, 254 F.2d 744 (D.C. Cir. 1958).

${ }_{311}$ Agreement $\S_{4}$. It was extended until Oct. 20, 1960 by an amendment of Oct. 13, 1959 . 
The Board indicated particular interest in the following five questions: $:^{112}$

x. Does the agreement violate any applicable provisions of the Railway Labor Act?

2. Will the operation of the agreement improve or impair labor-management relations in the industry?

3. Will the agreement discriminate in restraint of trade against other air carriers not parties to it?

4. What effect, if any, will the agreement have upon administration of the mail-pay program?

5. What effect, if any, will the agreement have upon the extent of Government participation in labor-management disputes?

The CAB also ordered the carriers to submit data concerning the operation of the agreement. Principally called for were reports of subsidiary agreements and arrangements, and the amount and calculation of strike losses and payments under the agreement. ${ }^{113}$

As of this writing, the carriers have reported a total of $\$ 6,051,527$ paid under the agreement ${ }^{114}$ for strikes totaling iıo days.

The unions attacked the agreement chiefly on the grounds that it is (a) a combination to agree in advance that no negotiations will take place, but that the contractors will stand on the recommendations of an emergency board, ${ }^{116}$ and (b) an attempt to impose industry-wide bargaining. ${ }^{116}$

That the unions' charges were not true, the carriers argued, was indicated not only by the terms of the agreement itself, but also by the events following its signing, which included offers by carriers in excess of emergency board recommendations. They also contended:

(a) That the agreement is fully consistent with and promotes the statutory policies of the Railway Labor Act, because the obligations thereunder arise only if the statutory procedures are violated, ${ }^{117}$ or after they have been completed and the union demands are inconsistent with the recommendations of a presidential emergency board. Congress intended that such recommendations, although not binding, should be persuasive as a basis for settlement rather than "flouted and disregarded."118 1958.

${ }^{119}$ Six Carrier Mutual Aid Pact Approval Proceedings, No. 9977, Order No. E-13233, CAB, Dec. 4, ${ }^{213}$ Id., Order No. E-13308, Dec. 22, 1958.

${ }^{114}$ Aviation' Daily, May 22, I959, p. 143. An arbitration award has been filed in Six Carrier Mutual Aid Pact Approval Proceedings, No. 9977, Order No. E-r 4897 , CAB, Feb. 3, 1960, holding American entitled to payment under the Pact in connection with the pilots' strike, because it was called before the procedures of the Railway Labor Act had been exhausted. American has received $\$ 3,372,205$ pursuant to the award. Aviation Daily, Feb. I9, I960, p. 308.

${ }^{116}$ Six Carrier Mutual Aid Pact Approval Proceedings, No. 9977, Brief of the International Association of Machinists and Brotherhood of Railway Clerks, CAB, 1959.

${ }^{110} \mathrm{Id}$. at 6.

${ }^{117}$ Id., Joint Brief of the Airline Parties, CAB, r959, p. $x 6$.

${ }^{128}$ Id. at I9. 
(b) That interunion and intra-union cooperation are common practices, and that what is sauce for the goose is sauce for the gander. ${ }^{119}$

(c) That "the basic problem is one of imbalance in labor-management relations." Because of the growth of union strength, the airlines have lost the economic capacity to deal individually with unions on equal terms. ${ }^{120}$

(d) By virtue of the agreement, the airlines are able to use revenue which ordinarily would be their own to bolster their weak economic position during strikes. The agreement, therefore, will deter strikes. ${ }^{121}$ "When the balance of power preponderates decisively in favor of the union, the temptation is great for the union to obtain its demands by striking rather than engaging in serious collective bargaining aimed at reconciling the interests of both parties.'י122

The airlines also contended that the agreement would not inject the $\mathrm{CAB}$ into the labor relations of the airline industry, that it was not inconsistent with the policies of the antitrust laws, and that it would not pose problems in the administration of the mail-pay program. ${ }^{123}$

In a press release dated January 26,1959 , the CAB indicated its approval of the agreement (by a four-to-one vote), and on May 20, I959, its opinion was issued (with a dissenting opinion by Board member Minetti)..$^{124}$ Approval was "subject to the following conditions": ${ }^{125}$

(a) The agreement should be amended by deleting clause 2 thereof, relating to routing of traffic by a struck carrier party;

(b) The approval referred to above shall not affect the rights and obligations of the parties, or of their employees, under the Railway Labor Act;

(c) The approval granted herein shall not be deemed a determination of the reasonableness of the financial provisions of the agreement for future rate-making or other regulatory purposes under the Act.

It also required the parties to continue making reports concerning the operation of the agreement.

In reaching its decision, the Board found, on the basis of the record before it, that the agreement would not "constitute an impediment to bona fide collective bargaining,"126 "interfere with the prompt settlement of disputes,"127 bring "into the dispute carriers not parties thereto," 128 or violate the Railway Labor Act. ${ }^{129}$ Nor would it cause "such a disparity in economic power as to jeopardize the attainment of the

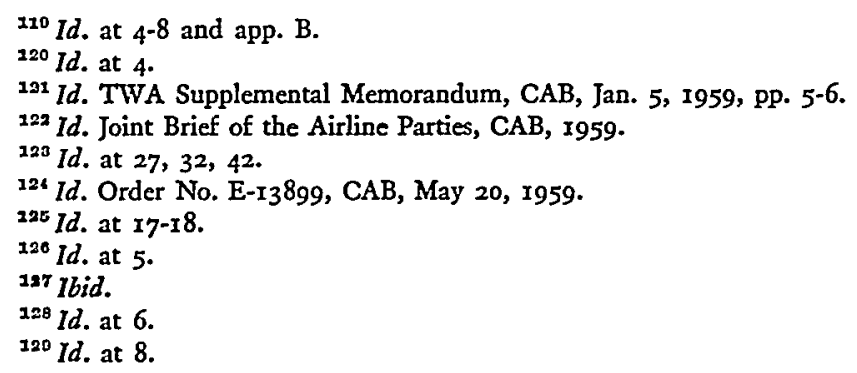


statutory objectives"130 of the Federal Aviation Act of $1958,8^{131}$ "destroy workable labor relations," 132 or "substantially lessen competition within the air transportation industry." 133

In so deciding, the Board did not make "any determination as to whether the agreement is a wise or beneficial step in the promotion of maximum harmony between labor and management, generally, or in air transportation in particular," since, as a statutory matter, its approval was required by "the lack of any affirmative showing that the agreement is adverse to the objectives specified by Congress."134

Deletion of the traffic-routing provision was required because the Board felt that the public should be advised of travel facilities on the basis of passenger convenience rather than carrier obligation and recognized that the provision "is not crucial to the purpose of the agreement."135

\section{Conclusions}

The Railway Labor Act's major dispute procedures have not been successful in accomplishing their primary objective-i.e., the settlement of such disputes without strikes. Some students, in fact, believe that the present statutory procedures actually impede peaceful settlements. Whether that is true or not, the fact remains that labor disputes in the recent past have been accompanied by a number of serious airline strikes. The consequences of such strikes have been demonstrated, time and time again, to be gravely injurious to the public interest in the uninterrupted transportation by air of persons, property, and mail. By forcing a complete shutdown of operations, such strikes also commonly result in loss of pay by employees having different bargaining representatives and, therefore, not concerned in the dispute.

Aside from whatever fundamental changes should be made in the major dispute provisions of the Act, therefore, the public interest would seem to require at the

$130 \mathrm{Id}$. at 10.

${ }^{131} 72$ Stat. 737, 49 U.S.C.A. $\$ \S 1301-1542$ (Supp. 1958).

${ }^{132}$ Six Carrier Mutual Aid Pact Approval Proceedings, No. 9977, Order No. E-13899, CAB, May 20, r959, p. II.

${ }^{133} I d$, at $\mathbf{r} 3$.

${ }^{13 s}$ Id. at 17.

${ }^{135} \mathrm{Id}$. at I2. This was accomplished by an amendment of June 5, 1959. In id. Order No. E-I4563, $\mathrm{CAB}$, Oct. I9, I959, p. 5, the Board denied a union petition for reconsideration of its approval of the mutual aid pact, stating: "The petition contains excerpts from the legislative history of the Railway Labor Act in an attempt to show that the intent of Congress was hostile to agreements such as the one before us. The congressional history, however, only confirms our original view that, in the Railway Labor Act, Congress restricted the ambit of its proscription against compulsion to governmental action, and laft the parties free to engage in reciprocal tests of economic strength within the framework of collective bargaining."

Wall Street Journal, Sept. 23, r959, p. 2, reported the formation of a "coordinating committee for unions in the air transport industry" with a purpose of devising an answer to the mutual aid paçt. $A$ union spokesman suggested that contracts be arranged to expire at about the same time, "so we can have unified collective bargaining." The six unions involved are the Air Line Dispatchers Association, the Air Line Pilots Association, the Brotherhood of Railway Clerks, the Flight Engineers International Association, the International Association' of Machinists, and the 'Transport Workers Union. 
very least that the privilege of resorting to strike action be preceded by and conditioned on a secret strike ballot in which an absolute majority of the employees concerned reject (a) the carrier's last offer, (b) the NMB's proffer of arbitration, and (c) the recommendations of a presidential emergency board, if any. If any one of the three items listed above were not so rejected, the union involved should not be permitted to resort to economic warfare. It seems obvious that such an election should be conducted by a public agency after both sides-the union and management-have had a full opportunity to explain their positions to the employees.

Moreover, many who have had experience in the field-including this writerhave felt that strike action has been taken in some cases to accomplish objectives which are not wholly in accord with either a sound system of air transportation or the public interest. Jurisdictional and employee-qualification disputes fall into this category. Such disputes should be settled by an agency charged with protecting the public interest rather than by the pressures of collective bargaining or the balance of economic power.

A further area for correction, important from an operational point of view, is the harassment caused by threatened illegal strike action. When such threats are made, management must take them seriously and prepare for them, whether or not the unions mean them seriously. Operational uncertainty and cost result-particularly when, as is frequently the case, such threats occur over holiday travel periods and judges are not readily available to restrain them. Threats of illegal strike action certainly can be no less damaging than defamatory statements. Persons making libelous or slanderous statements have common-law liability for them, and it would not seem unreasonable to hold unions making threats of illegal strikes answerable in damages at the very least.

The minor-dispute procedures of the Railway Labor Act have been fairly successful in adjusting such disputes without resort to strike action, and the recent Chicago River case ${ }^{136}$ should further strengthen those procedures. They are subject to abuse, however, and, where there is a will, there is a way to use them as an instrument of harassment. Moreover, they are unsuitable for disposing of jurisdictional disputes and troublesome problems where an individual grievance is asserted and the union itself is antagonistic to the claim.

The role of the NMB is ambiguous. The Board has correctly recognized that its primary role is mediatory, and it is probably right that the performance of certain other functions - which, nevertheless, badly need to be performed-would interfere with its effectiveness in mediation. Functions which perhaps might be performed by a separate agency include settlement of jurisdictional disputes, bargaining-unit determinations, and the conduct of representation elections.

The Railway Labor Act has been in operation for a sufficient period of time to warrant legislative review in the light of experience under it. The clamor accom-

${ }^{130}$ See supra note 90. 
panying recent airlines strikes is eloquent testimony to the public interest in such review and the correction of statutory deficiencies. ${ }^{137}$

\section{APPENDIX A}

The following chart was introduced in evidence as TWA Exhibit No. 53 by Mr. John P. Mead, Assistant Vice President of Personnel and Industrial Relations for Trans World Airlines, Inc., in the proceedings before Presidential Emergency Board No. r22. See 25 Transcript of Proceedings 2733 (1958). That Board investigated the disputes between the International Association of Machinists and six air carriers. The chart has been modified to reflect the 1959 settlements.

COMPARISON OF TW,A-IAM MECHANICS AND RELATED EMPLOYEES' WEIGHTED AVERAGE STRAIGHT TIME PAY (EXCLUDING SHIFT PREMIUMS) WITH THE (I) CONSUMER PRICE INDEX AND ANNUAL PRODUCTIVITY FACTOR, (2) TWA REVENUE PASSENGER MILE YIELD, AND (3) TWA REVENUE TON MILE YIELD, 1948-1959

(JANUARY $1948=$ I00)

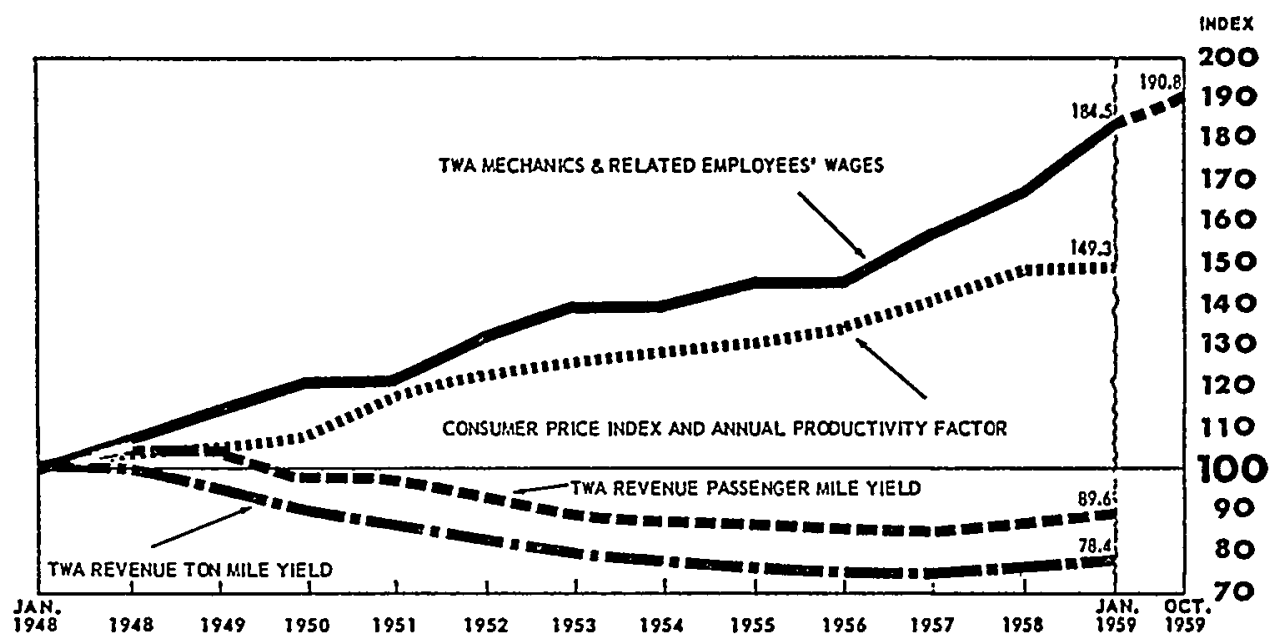

I. The Mechanics and Related Employees' wages for the various years are shown as of January $\mathrm{r}$ (except I948 which refers to wages after the April settlement).

2. The Consumer Price Index is as of January 15,1948 and January 15,1959 ; annual averages arc used for the years 1948 through 1958 .

3. The annual productivity factor used is 2.2. This is based on the BLS computation for 1909-1956.

4. The revenue yields are for January, 1948 and for the years $1948-1958$. The increase indicated in March, 1958 is attributable to the temporary passenger fare increase of $4 \%$ plus $\$ 1.00$ for each ticket granted by $\mathrm{CAB}$ in February. See Interim Fare Increase Case, No. 9288, Order No. E-r2203, CAB, Feb. 25, 1958 .

${ }^{137}$ Legislative review of the Railway Labor Act has been recommended from the standpoint of the railroad industry. See Railroad Passenger Deficit, No. 31954, ICC, May 18, 1959, pp. 52, 103. On the general subject of remedial legislation, see, MacIntyre, The Railway Labor Act-A Misfit for the Airlines, 19 J. AIr L. \& Com. 274 (1952). It is suggested therein that the airlines be brought under the National Labor Relations Act, as amended. 